\title{
Feeding Value of Singed Walkingstick Cholla
}

\author{
Rachel L. Endecott, ${ }^{1}$ Jason E. Sawyer, ${ }^{2}$ Clint A. Löest, ${ }^{3}$ \\ and Mark K. Petersen ${ }^{4}$ \\ Authors are ${ }^{1}$ Graduate Assistant, ${ }^{3}$ Assistant Professor, and ${ }^{4}$ Professor, Animal and Range Sciences Department, \\ New Mexico State University, Las Cruces, NM 88003; and ${ }^{2}$ Assistant Professor, Animal Science Department, \\ Texas A \& M University, College Station, TX 77843.
}

\begin{abstract}
Walkingstick cholla cactus (Opuntia imbricata [Haw.] DC) has been used in New Mexico as an emergency feed during drought for more than 100 years. Most reports present only the chemical composition of walkingstick cholla, and limited data exist regarding its feeding value. Three wethers (avg wt $65 \pm 7 \mathrm{~kg}$ ) were fed a basal diet of mature blue grama hay (Bouteloua gracilis [HBK] Lag. ex Steud., 9.0\% crude protein [CP] and 69.0\% neutral detergent fiber [NDF], organic matter [OM] basis) in a replicated $3 \times 3$ Latin square to determine digestibility of singed walkingstick cholla and to measure nitrogen balance. Treatments consisted of $0 \%, 15 \%$, and $20 \%$ walkingstick cholla in the diet on a dry matter (DM) basis. Walkingstick cholla contained 20.3\% DM, 79.6\% OM, 36.4\% NDF, and 9.0\% CP (OM basis). Walkingstick cholla clippings, consisting of green, nonwoody cladodes, were harvested in September. Cactus was singed with a propane torch until no spines remained, chopped, and added to the diet each day. Walkingstick cholla and hay were sampled daily and compiled by period. Total fecal and urine collections were subsampled and frozen for later analysis. Feed and fecal samples were analyzed for DM, OM, NDF, and nitrogen $(\mathrm{N})$; urine samples were analyzed for N. Nutrient digestibilities and N-retention values were calculated. Walkingstick cholla digestibilities were determined by difference. Mean walkingstick cholla DM, OM, NDF, and CP digestibilities averaged $32.6 \%, 44.3 \%, 27.9 \%$ and $67.6 \%$, respectively. Diet OM and CP digestibilities were similar for all treatments. Diet DM digestibility tended $(P=0.08)$ to decrease linearly with increasing dietary walkingstick cholla. As walkingstick cholla increased in the diet, NDF digestibility decreased linearly $(P=0.04)$. Because of its poor feeding value and low DM content, use of walkingstick cholla as an emergency feed should be carefully considered.
\end{abstract}

\section{Resumen}

En Nuevo México, por más de 100 años, el “walkingstick cholla cactus” (Opuntia imbricata [Haw.] DC) has sido utilizado como forraje de emergencia durante los periodos de sequía. La mayoría de los reportes presentan solo la composición química del "walkingstick cholla" y existen datos limitados respecto a su valor alimenticio. Tres carneros (peso promedio de $65 \pm 7 \mathrm{~kg}$ ) fueron alimentados con una dieta basal de heno de "Blue grama" (Bouteloua gracilis [HBK] Lag. ex Steud. maduro con 9.0\% de proteína cruda [PC] y $69.0 \%$ de fibra neutro detergente [FND], en base de materia orgánica [MO base]. El experimento se condujo en un diseño repetido de cuadro latino $3 \times 3$, para determinar la digestibilidad del "walkingstick cholla" chamuscado y medir el balance de nitrógeno. Los tratamientos consistieron de adicionar 0\%, 15\%, y 20\% de "walkingstick cholla" en la dieta en base de materia seca. El "walkingstick cholla” contenía 20.3\% MS, 79.6\% MO, 36.4\% FND, y 9.0\% PC (base MO). El forraje de "walkingstick cholla" consistía de cladodios verdes no lignificados que fueron cosechados en septiembre. El cactus fue quemado con un soplete de gas propano hasta que se eliminaron todas las espinas, fue picado y adicionado a la dieta de cada día. El "walkingstick cholla" y el heno se muestrearon diariamente y los datos fueron compiladas por periodo. La colección totales de heces y orina fueron submuestreadas y congeladas para análisis posteriores. Las muestras de heces y alimento fueron analizadas para determinar la MS, MO, FND y nitrógeno $(\mathrm{N})$; las muestras de orina fueron analizadas para determinas su contenido de N. Se calcularon los valores de digestibilidad de los nutrientes y la retención de N, las digestibilidades del "walkingstick cholla" se determinaron por diferencia. Las medias de digestibilidad de MS, MO, FND, y PC del "walkingstick cholla" promediaron 32.6\%, 44.3\%, 27.9\%, y 67.6\%, respectivamente. Las digestibilidades de la MO y PC de la dieta fueron similares en todos los tratamientos. La digestibilidad de la MS tendió $(P=0.08)$ a decrecer linealmente al aumentar el "walkingstick cholla" en la dieta. Conforme se incrementó el "Walkingstick cholla" en la dieta, la digestibilidad de la FND disminuyó linealmente $(P=0.04)$. Debido a su pobre valor alimenticio y bajo contenido de MS, el uso de "walkingstick cholla" como forraje de emergencia debe ser considerado cuidadosamente.

Key Words: cactus, digestibility, drought feeding, emergency feeds

Appreciation is expressed to New Mexico Agricultural Experiment Station for partial funding of study.

Correspondence: Rachel L. Endecott, Animal and Range Sciences Dept, New Mexico State University, Las Cruces, NM 88003. Email: rendecot@nmsu.edu

Manuscript received 4 October 2004; manuscript accepted 3 April 2005.

\section{INTRODUCTION}

Drought is a recurring situation faced by livestock producers in the West resulting in reduced forage quality and quantity. Under these conditions, it is often necessary to supply emergency feeds and to reduce herd size. Traditional supplemental 
Table 1. Nutrient composition of mature blue grama hay, cholla cactus, and diets consumed by wethers with cholla cactus as $0 \%, 15 \%$, or $20 \%$ of diet with mature blue grama hay.

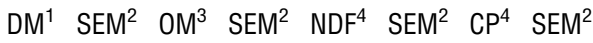

\begin{tabular}{|c|c|c|c|c|c|c|c|c|}
\hline \multicolumn{9}{|l|}{ Ingredient } \\
\hline Mature blue grama hay & 92.7 & 0.11 & 90.8 & 0.13 & 69.1 & 0.23 & 9.0 & 0.12 \\
\hline Walkingstick cholla & 20.3 & 0.88 & 79.6 & 0.38 & 36.4 & 1.40 & 9.9 & 1.80 \\
\hline \multicolumn{9}{|l|}{ Treatment (cholla \% of diet) } \\
\hline 0 & 92.7 & 0.11 & 90.8 & 0.13 & 69.1 & 0.23 & 9.0 & 0.12 \\
\hline 15 & 81.9 & 0.17 & 89.1 & 0.15 & 64.2 & 0.28 & 9.1 & 0.30 \\
\hline 20 & 78.3 & 0.20 & 88.5 & 0.16 & 62.5 & 0.33 & 9.1 & 0.38 \\
\hline
\end{tabular}

${ }^{1} \mathrm{DM}$ indicates dry matter percentage on an as-fed basis.

${ }^{2} n=6$. SEM indicates standard error of the mean.

${ }^{3} \mathrm{OM}$ indicates organic matter, expressed as a percentage of DM.

${ }^{4} \mathrm{NDF}$ indicates neutral detergent fiber; $\mathrm{CP}$, crude protein; both expressed as a percentage of $\mathrm{OM}$.

feeds, such as hay or grain, may be unavailable or costprohibitive during drought, and livestock producers may prefer a less-expensive alternative.

Walkingstick cholla (Opuntia imbricata [Haw.] DC) has been used as an emergency feed in New Mexico for more than 100 years (Griffiths and Hare 1906; Wooten 1911) and is an available resource across much of New Mexico (Pieper et al. 1974). Limited data exist regarding the feeding value of cholla cactus, and since the early work from the turn of the century, the only research concerning walkingstick cholla as a livestock feed was conducted by Sawyer et al. (2001), who compared chemical constituents and organic matter (OM) disappearance of burned and unburned walkingstick cholla cactus.

Although walkingstick cholla is common on New Mexico rangeland, most research concerning cactus as livestock feed has focused on spined and spineless prickly pear (plains pricklypear [Opuntia polyacantha Haw.], Shoop et al. 1977; spined prickly pear [Opuntia macrorhiza Engelm.], and spineless prickly pear [Opuntia rufida Engelm.], McMillan et al. 2002). Therefore, our objective was to assess the feeding value of singed walkingstick cholla by 1) evaluating its in vivo digestibility when fed with a basal diet of mature blue grama hay (Bouteloua gracilis (HBK) Lag. ex Steud.), and 2) examining the nitrogen $(\mathrm{N})$ balance of wethers consuming this diet.

\section{MATERIALS AND METHODS}

\section{Animals and Diets}

All animal procedures were approved by the New Mexico State University Institutional Animal Care and Use Committee. Three whiteface wethers (avg wt $65 \pm 7 \mathrm{~kg}$, mean $\pm \mathrm{SE}$ ) were used in 2 successive $3 \times 3$ Latin squares. Each square consisted of 3 periods and 3 treatments; wethers were assigned randomly to treatments with the exception that they could not repeat a treatment within a square. Treatments consisted of $0 \%, 15 \%$, and $20 \%$ walkingstick cholla in a blue grama haybased diet on a dry matter (DM) basis (treatments 0,15 , and 20). These percentages were consistent with amounts consumed by range cows grazing central New Mexico rangeland where stands of walkingstick cholla exist, based on observation of ruminal contents of ruminally fistulated cattle during diet sample collections (T. Dean, personal communication, August 2001). The experiment was planned with $0 \%, 15 \%$, and $30 \%$ walkingstick cholla in the diet (DM basis), but wethers restrained in metabolism crates would voluntarily consume a diet containing up to $20 \%$ walkingstick cholla. Wethers were fed twice daily (0600 and 1800 hours) at $1 \%$ of body weight per day (DM basis); this level of intake represents normal intake of range livestock during drought and also encouraged consumption of the entire daily amount of diet. Individual nutrient compositions of mature blue grama hay and walkingstick cholla used in this study were analyzed and nutrient composition of the total diet for each treatment was calculated (Table 1).

Walkingstick cholla was harvested at the Corona Range and Livestock Research Center (lat $34.26^{\circ} \mathrm{N}$, long $105.41^{\circ} \mathrm{W}$ ) in early September 2001. The Corona Range and Livestock Research Center (average elevation $=1900 \mathrm{~m}$; average annual precipitation $=400 \mathrm{~mm}$ ) is located $300 \mathrm{~km}$ northeast of Las Cruces, NM, and $160 \mathrm{~km}$ southeast of Albuquerque, NM. Total precipitation for 2 years preceding the study (September 1999 through August 2001) was $669 \mathrm{~mm}$, compared with the 1994-2001 average of $777 \mathrm{~mm}$. Cactus clippings consisted of green, nonwoody terminal cladodes, which appear to be preferred segments when cows are browsing walkingstick cholla (T. Dean, personal communication, August 2001). The stand of walkingstick cholla from which clippings were taken was small $(100 \mathrm{~m} \times 100 \mathrm{~m})$, and individual plants in the stand were uniform in size, approximately $2 \mathrm{~m}$ tall and $1.5 \mathrm{~m}$ wide. The clippings were transported to the New Mexico State University livestock center in Las Cruces and stored under tarps throughout the duration of the study to prevent weathering. Walkingstick cholla was burned in batches (to provide 1 week's supply) with a propane torch until no spines remained and little to no singeing of the green portion of the plant occurred. Burned segments were then chopped with a knife into an average of $5 \times 2.5 \mathrm{~cm}$ pieces and added to the mature blue grama hay diet each day. When cows browse walkingstick cholla, they consume segments approximately the same size as those fed to the wethers (personal observation; S. Cox, personal communication, August 2001), and chopping also improved acceptability and reduced sorting of walkingstick cholla from basal diet.

\section{Sampling Methods}

Each 12-day experimental period consisted of a 7-day adaptation phase followed by a 5-day collection phase. During adaptation phase, wethers were housed outdoors in adjacent, individual pens, and during collection phase, they were placed in metabolism crates to allow for separate collection of urine and feces. Total fecal and urine output were collected twice daily on days 8 through 12 . Ten milliliters of $6 \mathrm{~N} \mathrm{HCl}$ were added to the urine collection container to prevent ammonia volatilization. Ten percent aliquots of feces and urine were reserved each day, composited by experimental period, and frozen for later analysis. Walkingstick cholla and hay were separately sampled daily and composited for each period, and walkingstick cholla samples were frozen for later analysis. Feed and fecal samples were analyzed for DM, OM, Kjeldahl $\mathrm{N}$ (AOAC 2000), and neutral detergent fiber (NDF, Van Soest et al. 1991); urine samples were analyzed on a wet basis for Kjeldahl N. All samples were analyzed in duplicate, except for 
fecal, walkingstick cholla, and urine Kjeldahl N, which were analyzed in triplicate.

Nutrient digestibilities and $\mathrm{N}$ retention were chosen to evaluate feeding value as these measures assess overall nutrient quality of a diet and estimate protein use, respectively. These criteria are often used to characterize the quality of range livestock diets and were used because in vivo data on the nutritional value of walkingstick cholla were limited. Nutrient digestibility and $\mathrm{N}$ retention were calculated using the following equations.

$$
\begin{aligned}
\text { Nutrient digestibility }= & (\text { Nutrient intake }- \text { Nutrient in feces }) / \\
& \text { Nutrient intake } \\
N \text { retention }= & {[N \text { intake }-(N \text { in feces }+N \text { in urine })] / } \\
& N \text { intake }
\end{aligned}
$$

Walkingstick cholla digestibilities were determined by difference, assuming constant digestibility of blue grama hay.

$$
\begin{aligned}
& \text { Cholla nutrient digestibility } \\
& \begin{array}{l}
=[\text { Total diet nutrient digestibility } \\
\quad-(\% \text { Hay in diet } \times \text { Hay nutrient digestibility })] / \\
\quad \% \text { Cholla in diet }
\end{array}
\end{aligned}
$$

Total diet digestibility was calculated using Equation [1] for each treatment. Hay digestibility was calculated using Equation [1] for treatment 0.

\section{Statistical Analysis}

Data were analyzed by analyses of variance (ANOVA) using the general linear model procedures of SAS (2000). All data were analyzed with animal (3), period (6), and treatment (3) as effects in the model. Orthogonal polynomial contrasts were used to test for linear and quadratic effects of increasing walkingstick cholla concentration in the diet.

\section{RESULTS AND DISCUSSION}

Dry matter content of cactus fluctuates throughout the year, although most reports agree DM content is lowest in summer months. Walkingstick cholla used for this experiment was harvested in September and contained 20.3 $\pm 0.88 \%$ DM (Table 1). Dry matter values for plains prickly pear ranged from $14.6 \%$ in June to $45.8 \%$ in February in Colorado (Shoop et al. 1977). Pieper et al. (1974) found DM content of walkingstick cholla in New Mexico was 16\%-20\% during summer and increased to $38 \%$ in February. Walkingstick cholla harvested in June at the Corona Range and Livestock Research Center had a DM percentage of 12.7\% (Sawyer et al. 2001). Regardless of harvest date, a large amount of walkingstick cholla must be fed or browsed to make up a notable part of an animal's diet dry matter. OM (79.6 $\pm 0.38 \%)$ and NDF $(36.4 \pm 1.4 \%)$ concentrations for walkingstick cholla agree with those $(81.0 \%$ OM; 39.2\% NDF) observed by Sawyer et al. (2001). Crude protein content of walkingstick cholla $(9.9 \pm 1.8 \%)$ was less than the $13.6 \%$ CP for walkingstick cholla reported by Sawyer et al. (2001) and greater than the $5.3 \%$ CP and 4.8\% CP reported by Shoop et al. (1977) and
McMillan et al. (2002) for plains prickly pear and singed prickly pear, respectively.

In vivo digestibilities for walkingstick cholla cactus were calculated to be $32.6 \pm 12.7 \%$ and $44.3 \pm 12.6 \%$ for DM and $\mathrm{OM}$, respectively. These digestibilities were much lower than in situ and in vivo values from other reports for prickly pear or cholla cacti. Shoop et al. (1977) found an in situ DM digestibility value of $66.4 \%$ for pricklypear cactus after 48 hours of incubation, whereas Meyer and Brown (1985) reported an in vitro DM digestibility of $75.7 \%$ for prickly pear in Texas. McMillan et al. (2002) found an in vivo DM digestibility of singed prickly pear of $58.0 \%$ and an OM digestibility of $70.0 \%$. Sawyer et al. (2001) found in situ OM disappearance of walkingstick cholla to be $77.3 \%$ after 20 hours of incubation. Calculated in vivo NDF and CP digestibilities of walkingstick cholla from the present study $(27.9 \pm 18.9 \%$ and $67.6 \pm 12.4 \%$, respectively) are more comparable with in situ values reported by Batista et al. (2002) for 3 varieties of spineless cacti in Brazil (39.5\% NDF digestibility and $59.9 \%$ CP digestibility). A potential explanation for discrepancies between our results and other reports could be because of one of the physical attributes of walkingstick cholla. The outside covering of walkingstick cholla, like other cacti, is composed of waxy cutin and is quite dense and impenetrable. Animals may not have the ability to adequately reduce particle size of walkingstick cholla during mastication. Unlike prickly pear, the pulp of walkingstick cholla has a very fibrous inner skeleton that may further impede particle-size reduction. Therefore, the method of grinding samples to 1 to 2 $\mathrm{mm}$ typically used for nylon bag (in situ) or in vitro digestibility determination may decrease particle size to a greater extent than is achieved via animal mastication, resulting in artificially inflated estimates of degradation relative to in vivo observations, although chemical composition data are comparable.

DM and CP digestibilities for total diet (hay plus walkingstick cholla) were similar $(P \geq 0.10)$ for all animals, whereas OM digestibility tended $(P=0.08)$ to be different among wethers, and NDF digestibility varied $(P=0.01)$ among animals. One wether had consistently lower OM and NDF digestibility values, which was attributed to inherent individual animal variation.

Crude protein digestibility was similar $(P \geq 0.22)$ for all periods. A period effect existed for DM, OM, and NDF digestibilities $(P<0.01)$; digestibility values from period 1 were lower than those from periods $2-6$. This was attributed to wethers' incomplete adaptation to metabolism crates in period 1.

OM and CP digestibilities for total diet were similar for all treatments (Table 2), although diet OM digestibility declined numerically with increasing walkingstick cholla concentration. Diet DM digestibility tended $(P=0.08)$ to decrease linearly as walkingstick cholla increased in the diet. NDF digestibility decreased $(P=0.04)$ linearly with increasing walkingstick cholla in the diet.

A period effect was observed for $\mathrm{N}$ intake $(P=0.03)$, and fecal $\mathrm{N}$ tended to be different among periods $(P=0.08)$. No apparent trend was noted, but values were always lower in period 1 when compared with periods $2-6$, again attributed to incomplete adaptation of wethers to metabolism crates.

$\mathrm{N}$ intake decreased linearly $(P<0.01)$, and fecal $\mathrm{N}$ decreased quadratically $(P=0.03)$ with increasing walkingstick 
Table 2. Nutrient digestibilities and daily nitrogen intake, excretion, and retention in wethers consuming cholla cactus as $0 \%, 15 \%$, or $20 \%$ of the diet with mature blue grama hay.

\begin{tabular}{lccccccc}
\hline & \multicolumn{3}{c}{ Cholla percent of diet } & & \multicolumn{2}{c}{ Contrast } \\
\cline { 2 - 4 } Item & 0 & 15 & 20 & SEM & & $\mathrm{L}^{1}$ & $\mathrm{Q}^{2}$ \\
\hline DM digestibility, \% & 52.6 & 50.2 & 47.8 & 1.6 & & 0.08 & 0.60 \\
OM digestibility, \% & 59.3 & 57.7 & 55.4 & 1.6 & & 0.16 & 0.54 \\
NDF digestibility, \% & 58.0 & 54.2 & 51.0 & 1.9 & & 0.04 & 0.57 \\
CP digestibility, \% & 63.1 & 61.9 & 66.5 & 1.9 & & 0.41 & 0.16 \\
Intake N, g & 6.00 & 5.64 & 5.08 & 0.14 & & $<.01$ & 0.10 \\
Fecal N, g & 2.22 & 2.15 & 1.68 & 0.10 & & 0.01 & 0.03 \\
Urine N, g & 3.86 & 3.52 & 3.80 & 0.30 & & 0.72 & 0.45 \\
Retained N, g & -0.07 & -0.02 & -0.41 & 0.39 & & 0.66 & 0.56 \\
\hline
\end{tabular}

${ }^{1}$ Linear contrast for level of cholla in diet.

${ }^{2}$ Quadratic contrast for level of cholla in diet.

cholla in the diet (Table 2). Intake of $\mathrm{N}$ decreased because wethers refused an average of $0.5,1.9$, and $2.1 \mathrm{~g} \mathrm{~N}$ per day for treatments 0,15 , and 20 , respectively. Urinary $\mathrm{N}$ excretion and $\mathrm{N}$ retained were similar for all treatments. $\mathrm{N}$ retention values were consistent with rates of intake and the physiological state of wethers used in this experiment. $\mathrm{N}$ retention as a proportion of $\mathrm{N}$ intake was similar for all treatments $(-0.02 \%,-0.02 \%$, and $-0.09 \% \pm 0.07$ for treatments 0,15 , and 20 , respectively). Low values were unsurprising as low-digestibility diets often result in relatively high endogenous $\mathrm{N}$ losses (Minson 1990). The addition of walkingstick cholla cactus up to $20 \%$ of the diet did not negatively impact $\mathrm{N}$ retention.

\section{MANAGEMENT IMPLICATIONS}

Under drought conditions, energy is often the most limiting nutrient because of reduced forage availability. Walkingstick cholla, when fed as an emergency feed, would be used to supply energy. Because of the low DM content of walkingstick cholla, a large amount must be fed to make up a notable part of diet DM. Although laboratory, in situ, and in vitro measurements indicate walkingstick cholla is readily digestible, physical characteristics may reduce its digestibility and consequently its energy value in a practical setting (in vivo). The true feeding value of walkingstick cholla is lower than expected based on chemical composition, and producers should carefully consider the use of walkingstick cholla cactus as an emergency feed.

\section{LITERATURE CITED}

[AOAC] Association of Official Analytical Chemists. 2000. Official methods of analysis. 17th ed. Gaithersburg, MD: AOAC. 2,200 p.

Batista, A., A. Mustafa, and I. Adeleye. 2002. Chemical characterization and ruminal nutrient degradabilities of spineless cacti [abstract]. Journal of Animal Science 85(Suppl):386.

Griffiths, D., and R. F. Hare. 1906. Prickly pear and other cacti as food for stock II. Mesilla Park, NM: New Mexico College of Agriculture and Mechanical Arts. Bulletin 60 .

McMillan, Z., C. B. Scott, C. A. Taylor, JR., and J. E. Huston. 2002. Nutritional value and intake of prickly pear by goats. Journal of Range Management 55:139-143.

Meyer, M. W., and R. D. Brown. 1985. Seasonal trends in the chemical composition of ten range plants in south Texas. Journal of Range Management 38:154-157.

Minson, D. J. 1990. Forage in ruminant nutrition. San Diego, CA: Academic Press, Inc. $483 p$

Pieper, R. D., K. H. Rea, and J. G. Fraser. 1974. Ecological characteristics of walkingstick cholla. Las Cruces, NM: New Mexico Agriculture Experiment Station, New Mexico State University. Bulletin 623.

SAS. 2000. SAS user's guide. Cary, NC: SAS Institute, Inc.

Sawyer, J. E., L. A. Knox, G. B. Donart, and M. K. Petersen. 2001. The nutritive quality of cholla cactus as affected by burning. Journal of Range Management 54:249-253.

Shoop, M. C., E. J. Alford, and H. F. Mayland. 1977. Plains pricklypear is a good forage for cattle. Journal of Range Management 30:12-17.

Van Soest, P. J., J. B. Robertson, and B. A. Lewis. 1991. Methods for dietary fiber, neutral detergent fiber, and nonstarch polysaccharides in relation to animal nutrition. Journal of Dairy Science 74:3583-3597.

Wooten, E. 0. 1911. Cacti as fodder for livestock. Las Cruces, NM: New Mexico Agriculture Experiment Station, New Mexico State University. Bulletin 78. 